\title{
Productivity of Timahdite and D'man $\times$ Timahdite ewes lambing in the autumn, spring and summer in Morocco
}

\author{
Ismaïl BOUJENANE ${ }^{\mathrm{a} *}$, Mohamed Fatah CISSE$^{\mathrm{a}}$, JAOUAD KANSARI ${ }^{\mathrm{b}}$ \\ a Department of Animal Production, Institut Agronomique et Vétérinaire Hassan II, \\ PO Box 6202 Rabat-Instituts, 10101 Rabat, Morocco \\ ${ }^{\text {b }}$ Société Nationale de Développement de l'Élevage, 5 rue de Salé, Hassan, Rabat, Morocco
}

(Received 29 April 2004; accepted 22 October 2004)

\begin{abstract}
The reproductive performance of 1117 Timahdite and D'man $\times$ Timahdite $(D \times T)$ ewes lambing in the autumn, spring and summer, and weights and survival to 90 days of their 968 lambs were evaluated. All ewes were exposed to Meat Lacaune rams. The lambing rate of Timahdite ewes was $42 \%$ lower than that of $\mathrm{D} \times \mathrm{T}$ ewes. The litter size at birth and at 90 days of $\mathrm{D} \times \mathrm{T}$ ewes was 0.23 and $0.19 \mathrm{lamb}$, respectively greater than those of Timahdite ewes. $\mathrm{D} \times \mathrm{T}$ crossbred ewes weaned $4.1 \mathrm{~kg}$ weight more than Timahdite ewes. The lambing rate, litter size at 90 days and litter weight at birth and at 90 days of summer-lambing ewes were $43 \%, 0.39 \mathrm{lamb}, 0.23 \mathrm{~kg}$ and $17.7 \mathrm{~kg}$, respectively lower than those of autumn-lambing ewes. They were also 25\%, $0.49 \mathrm{lamb}, 1.3 \mathrm{~kg}$ and $14.6 \mathrm{~kg}$, respectively lower than those of spring-lambing ewes. The dam's genetic group had significant effects on lamb birth weight, but not on weight at 30 days and 90 days and survival. Spring-born lambs had the highest birth weight and survival, and autumn-born lambs had the highest weight at 30 days and 90 days. It was concluded that $\mathrm{D} \times \mathrm{T}$ crossbred ewes had better productivity than Timahdite ewes at any lambing season. Furthermore, flocks that rely on pasture for their nutrition should avoid summer lambing, which results in low ewe and lamb performance.
\end{abstract}

\section{sheep / Timahdite / D'man cross / reproduction / weight}

Résumé - Productivité des brebis Timahdite et D'man $\times$ Timahdite agnelant à l'automne, au printemps et en été au Maroc. Les performances de reproduction de 1117 brebis de race Timahdite et croisées D'man $\times$ Timahdite $(\mathrm{D} \times \mathrm{T})$ ayant agnelé à l'automne, au printemps et en été, ainsi que les poids et la viabilité à 90 jours de leurs 968 agneaux, ont été évaluées. Toutes les brebis ont été mises à la lutte avec des béliers de race Lacaune viande. Le taux d'agnelage des brebis Timahdite a été inférieur de $42 \%$ à celui des brebis $\mathrm{D} \times \mathrm{T}$. La taille de la portée à la naissance et à 90 jours des brebis $\mathrm{D} \times \mathrm{T}$ a été, respectivement, plus élevée de 0,23 et 0,19 agneau. De même, le poids de portée au sevrage des brebis $\mathrm{D} \times \mathrm{T}$ a été supérieur de $4,1 \mathrm{~kg}$. Pour les brebis ayant agnelé en été, le taux d'agnelage, la taille de la portée à 90 jours, le poids de portée à la naissance et à 90 jours ont été respectivement inférieurs de : $43 \%, 0,39$ agneau, $0,23 \mathrm{~kg}$ et 17,7 $\mathrm{kg}$ par rapport aux brebis ayant agnelé à l'automne. Par rapport aux brebis ayant agnelé au printemps, ils ont été inférieurs de $25 \%$, 0,49 agneau, $1,3 \mathrm{~kg}$ et $14,6 \mathrm{~kg}$, respectivement. Le groupe génétique de la mère a eu un effet

\footnotetext{
* Corresponding author: i.boujenane@iav.ac.ma
} 
significatif sur le poids à la naissance, mais pas sur les poids à 30 et 90 jours, et la viabilité des agneaux. Les agneaux nés au printemps ont eu le poids à la naissance et la viabilité les plus élevés, et les agneaux nés à l'automne les poids à 30 et 90 jours les plus élevés. En conclusion, la productivité des brebis $\mathrm{D} \times \mathrm{T}$ a été meilleure que celle des brebis Timahdite quelle que soit la saison d'agnelage. De plus, l'agnelage en été des troupeaux conduits sur parcours est à éviter, il engendre une réduction des performances des brebis et des agneaux.

ovins / Timahdite / croisé D'man / reproduction / poids

\section{INTRODUCTION}

Different strategies may be applied to increase sheep productivity: frequent lambing and high prolificacy of ewes or rapid growth rate of lambs. In Morocco, in order to improve the prolificacy of ewes, the prolific D'man breed is used to produce crossbred ewes, which are subsequently mated to a terminal sire. Also, crossing non-prolific local ewes to meat-type rams in order to improve lamb growth is a widely accepted practice among Moroccan breeders. The D'man is a prolific breed having a litter size at birth of 1.9 lambs, a precocious puberty (5 to 6 months old) and a long breeding season (all the year round with a slight decline in March and April) [2]. The Timahdite is a non-prolific local breed (1.05 lambs) known for its hardiness, satisfactory milk production and longevity [3]. Its breeding season extends from May to December [12]. D'man crossbred ewes were evaluated during the normal lambing season (November-January) and found to perform better than local breeds [5-7, 10]. However, it is not known if this superiority is maintained during the other lambing seasons.

Thus, the objective of this study was to evaluate reproductive performance and lamb weight and survival of Timahdite and D'man $\times$ Timahdite ewes lambing in the autumn, spring and summer.

\section{MATERIALS AND METHODS}

\subsection{Localisation and climate}

The ewes and lambs used in the present study were raised at the Had Soualem farm located on the Atlantic coast $\left(33^{\circ} 13^{\prime} \mathrm{N}, 7^{\circ}\right.$ $57^{\prime} \mathrm{W}$ ). The maximum and minimum temperatures, respectively, occur in July-August $\left(27.3^{\circ} \mathrm{C}\right)$ and in December-January $\left(6.8^{\circ} \mathrm{C}\right)$. The average annual rainfall was $371 \mathrm{~mm}$.

\subsection{Animals and management}

The performance data came from ewes of the Timahdite breed and D' man $\times$ Timahdite cross $(\mathrm{D} \times \mathrm{T})$. Age of Timahdite and $\mathrm{D} \times \mathrm{T}$ ewes averaged 68.0 months (ranging from 24 to 98 months) and 50.4 months (ranging from 23 to 82 months), respectively. The sheep were herded on range on a year round basis in flocks of approximately 180 ewes. At breeding, the ewes of each flock were exposed for 60 days during the night, without the use of hormone treatment, to several Meat Lacaune rams at a ram:ewe ratio of 1:30. During the day, rams were kept in the barn, where they received hay and concentrate, while ewes went on pasture. Breeding occurred from June 1 to July 31, 2000, from October 1 to November 30, 2000, and from March 1 to April 30, 2001, resulting in autumn (November to January), spring (March to April), and summer (August to September) lambings, respectively. The ewes were separated into two flocks in the autumn, three flocks in the spring and two flocks in the summer. Each flock was a mixture of Timahdite and $\mathrm{D} \times$ $\mathrm{T}$ ewes.

Ewes were on improved pasture during the winter and spring and on cereal stubble during the summer and early autumn. They never received any supplementary feed, except at the end of pregnancy and during suckling, when concentrate and molasses 
were provided. At birth, the lambs were eartagged, and their birth date, type of birth and sex were recorded. Lambs remained with their dams until weaning that occurred at about 90 days. During this period, they were weighed at birth and every three weeks until weaning, vaccinated against enterotoxemia, and treated for internal parasites. Lamb mortality was also recorded.

\subsection{Variables studied}

The reproductive traits studied included lambing rate (defined as 1 or 0 for ewes that lambed or failed to lamb, respectively), litter size at birth (number of lambs born alive per ewe lambing), litter size at 90 days (number of lambs weaned per ewe lambing), litter weight at birth (total lamb weight at birth per ewe lambing), and litter weight at 90 days (total lamb weight at 90 days per ewe lambing). The lamb traits examined were survival from birth to 90 days, weight at birth, 30 days and 90 days. The latter two weights were calculated by linear interpolation.

\subsection{Statistical analyses}

The analysed data included 1117 exposures, 783 lambings and 968 births. The number of ewes exposed and the number of lambs born per ewe's genetic group and season of lambing / birth are presented in Table I. Least squares analyses were conducted using the GLM procedure of SAS/STAT [16] to identify non-genetic factors influencing reproductive, growth and survival traits. The general statistical model used to analyse reproductive traits included effects of the ewe's genetic group (Timahdite and $\mathrm{D} \times \mathrm{T}$ ), age of ewe $(\leq 30,31-42,43-54$ and 55 months or older), lambing season (autumn, spring, and summer), and flock nested within lambing season (1 to 7). The factors considered in the model for lamb weight and survival were similar to those of the previous model, plus sex (male and female), and type of birth (single and twin or greater) for birth weight and survival, and type of birth-rearing (singlesingle, twin or greater-twin or greater and twin or greater-single) for weight at 30 days and 90 days. All effects were assumed to be fixed, except for the effects of flock and residual error that were assumed random. First-order interactions among fixed effects for ewe reproductive traits and lamb weight and survival were tested. Those that were significant were included in the final model. Higher order interactions were assumed negligible. Significant differences among means $(P<0.05)$ were examined by the Duncan new multiple range test [9].

\section{RESULTS AND DISCUSSION}

\subsection{Reproductive traits}

Except litter size at birth, which was not influenced by the season of lambing, the genetic group of ewe and season of lambing

Table I. Number of ewes exposed and lambs born alive per genetic group and lambing season.

\begin{tabular}{|c|c|c|c|c|c|c|}
\hline \multirow{3}{*}{ Season } & \multicolumn{3}{|c|}{ Ewes exposed } & \multicolumn{3}{|c|}{ Lambs born alive } \\
\hline & \multicolumn{2}{|c|}{ Genetic group of ewe } & \multirow[t]{2}{*}{ Total ewes } & \multicolumn{2}{|c|}{ Genetic group of dam } & \multirow[t]{2}{*}{ Total lambs } \\
\hline & Timahdite & $\mathrm{D} \times \mathrm{T}$ & & Timahdite & $\mathrm{D} \times \mathrm{T}$ & \\
\hline Autumn & 218 & 149 & 367 & 215 & 200 & 415 \\
\hline Spring & 279 & 144 & 423 & 171 & 182 & 353 \\
\hline Summer & 117 & 210 & 327 & 49 & 151 & 200 \\
\hline Total & 614 & 503 & 1117 & 435 & 533 & 968 \\
\hline
\end{tabular}

$\mathrm{D} \times \mathrm{T}$ : D'man $\times$ Timahdite crossbred ewes. 
Table II. Least squares means \pm SE for reproductive traits of Timahdite and $\mathrm{D} \times \mathrm{T}$ ewes ${ }^{1}$.

\begin{tabular}{lccccccc}
\hline Factor & n & $\begin{array}{c}\text { Lambing } \\
\text { rate }(\%)\end{array}$ & n & $\begin{array}{c}\text { Litter size at } \\
\text { birth }\end{array}$ & $\begin{array}{c}\text { Litter weight } \\
\text { at birth }(\mathrm{kg})\end{array}$ & $\begin{array}{c}\text { Litter size at } \\
90 \text { days }\end{array}$ & $\begin{array}{c}\text { Litter weight at } \\
90 \text { days }(\mathrm{kg})\end{array}$ \\
\hline $\begin{array}{l}\text { Genetic group of } \\
\text { ewe }\end{array}$ & & $* * *$ & & $* * *$ & $* *$ & $* *$ & $* * *$ \\
$\quad \begin{array}{l}\text { Timahdite } \\
\mathrm{D} \times \mathrm{T}\end{array}$ & 614 & $43 \mathrm{a} \pm 5.7$ & 393 & $1.15 \mathrm{a} \pm 0.04$ & $4.62 \mathrm{a} \pm 0.13$ & $0.94 \mathrm{a} \pm 0.04$ & $18.2 \mathrm{a} \pm 0.90$ \\
Season of lambing & 503 & $85 \mathrm{~b} \pm 3.6$ & 390 & $1.38 \mathrm{~b} \pm 0.03$ & $5.13 \mathrm{~b} \pm 0.11$ & $1.13 \mathrm{~b} \pm 0.04$ & $22.3 \mathrm{~b} \pm 0.78$ \\
Autumn & & $* * *$ & & $\mathrm{NS}$ & $* * *$ & $* * *$ & $* * *$ \\
Spring & 367 & $84 \mathrm{a} \pm 3.7$ & 339 & $1.22 \pm 0.03$ & $4.61 \mathrm{a} \pm 0.11$ & $1.13 \mathrm{a} \pm 0.04$ & $27.2 \mathrm{a} \pm 0.79$ \\
Summer & 423 & $66 \mathrm{~b} \pm 3.1$ & 282 & $1.31 \pm 0.04$ & $5.68 \mathrm{~b} \pm 0.13$ & $1.23 \mathrm{~b} \pm 0.04$ & $24.1 \mathrm{~b} \pm 0.86$ \\
\hline
\end{tabular}

${ }^{1}$ Least squares means within a column followed by different letter differ $(P<0.05)$;

NS: $P>0.05 ;{ }^{*}: P<0.05 ;{ }^{* *}: P<0.01 ;{ }^{* * *}: P<0.001$.

significantly affected all reproductive traits studied. Least squares means and standard errors for lambing rate, litter size at birth and at 90 days and litter weight at birth and at 90 days are presented in Table II.

During the three lambing seasons, lambing rate of Timahdite ewes was $42 \%$ lower than that of $\mathrm{D} \times \mathrm{T}$ ewes. The low lambing rate of Timahdite ewes may be due to their short breeding season compared to that of $\mathrm{D} \times \mathrm{T}$ crossbred ewes. The sexual activity of Timahdite ewes generally begins in May-June and ends by December [12], whereas the cyclic activity in the D'man breed and its crosses extends all year round, with low activities restricted to a short period [13]. Additionally, the low lambing rate of Timahdite ewes compared to $\mathrm{D} \times \mathrm{T}$ ewes may be due to their older age, since reproductive performance decreases when ewes become very old.

The lambing rate of ewes varied according to the season of lambing. Ewes lambing in the autumn had a lambing rates $18 \%$ and $43 \%$ higher than those of ewes lambing in the spring and summer, respectively. This confirmed the environmental and neuroendocrinal control of the breeding season in Moroccan sheep indicating an increase in the sexual activity of sheep during the period of June-December (short day length after the summer solstice of June 21st) and a decline during the remaining period of the year (long day length after the winter solstice of December 22nd). This was different from what is found at more northern latitudes, where May and June are the height of the anestrous period for many breeds of sheep. Moreover, the low lambing rate of summer-lambing ewes may also be explained by some decline in libido and semen quality of Lacaune rams during breeding that occurs in the spring, as noticed for rams of local breeds. Aboul-Naga et al. [1] showed that the fertility of Finnsheep and crosses with Rahmani and Ossimi breeds under accelerated lambing in Egypt was higher for ewes mated in January than in May and September. An interaction between the genetic group of ewe and season of lambing had significant effects on the lambing rate. The difference between lambing rate of $\mathrm{D} \times \mathrm{T}$ and Timahdite ewes increased from $15 \%$ in autumn, to $40 \%$ in spring to $74 \%$ in summer lambing, indicating that fewer Timahdite ewes were cycling during the autumn and spring mating season because again of their restricted breeding season.

Litter size at birth varied from 1 to 2 for Timahdite ewes and from 1 to 3 for $\mathrm{D} \times \mathrm{T}$ crossbred ewes. Single and twin litters represented $89.3 \%$ and $10.7 \%$, respectively for Timahdite ewes, whereas single, twin and triplet litters represented $66.2 \%, 31.3 \%$ and 
Table III. Least squares means \pm SE for weights and survival of lambs from Timahdite and $\mathrm{D} \times \mathrm{T}$ dams ${ }^{1}$.

\begin{tabular}{|c|c|c|c|c|c|c|c|c|}
\hline Factor & $\mathrm{n}$ & $\begin{array}{c}\text { Birth weight } \\
(\mathrm{kg})\end{array}$ & $\mathrm{n}$ & $\begin{array}{c}\text { Weight at } \\
30 \text { days }(\mathrm{kg})\end{array}$ & $\mathrm{n}$ & $\begin{array}{c}\text { Weight at } \\
90 \text { days }(\mathrm{kg})\end{array}$ & $\mathrm{n}$ & $\begin{array}{c}\text { Survival } \\
\text { 0-90 days } \\
(\%)\end{array}$ \\
\hline Genetic group of dam & & $* *$ & & NS & & NS & & NS \\
\hline Timahdite & 435 & $4.09 \mathrm{a} \pm 0.14$ & 414 & $8.95 \pm 0.24$ & 393 & $16.3 \pm 0.56$ & 435 & $78 \pm 2.3$ \\
\hline $\mathrm{D} \times \mathrm{T}$ & 533 & $3.62 b \pm 0.05$ & 499 & $8.82 \pm 0.20$ & 465 & $17.1 \pm 0.48$ & 533 & $81 \pm 1.8$ \\
\hline Season of birth & & $* * *$ & & $* * *$ & & $* * *$ & & $* * *$ \\
\hline Autumn & 415 & $3.64 \mathrm{a} \pm 0.09$ & 410 & $9.87 \mathrm{a} \pm 0.20$ & 395 & $21.7 \mathrm{a} \pm 0.48$ & 415 & $93 \mathrm{a} \pm 2.0$ \\
\hline Spring & 353 & $4.32 b \pm 0.08$ & 345 & $9.63 \mathrm{a} \pm 0.21$ & 338 & $17.8 b \pm 0.49$ & 353 & $93 \mathrm{a} \pm 2.0$ \\
\hline Summer & 200 & $3.61 \mathrm{a} \pm 0.09$ & 158 & $7.17 b \pm 0.27$ & 125 & $10.6 \mathrm{c} \pm 0.71$ & 200 & $51 \mathrm{~b} \pm 2.7$ \\
\hline
\end{tabular}

${ }^{1}$ Least squares means within a column followed by different letter differ $(P<0.05)$;

NS: $P>0.05 ;{ }^{*}: P<0.05 ;{ }^{* *}: P<0.01 ;^{* * *}: P<0.001$.

$2.6 \%$, respectively for $\mathrm{D} \times \mathrm{T}$ crossbred ewes. These frequencies varied from one lambing season to the other, with a high frequency of multiple litters in the autumn and spring, with a litter size not exceeding 2 lambs for both Timahdite and $\mathrm{D} \times \mathrm{T}$ ewes in summer lambings. Similar low September multiple litters were observed by Notter and Copenhaver [14] among Finn-cross and Suffolk $x$ Rambouillet ewes.

Litter size of $\mathrm{D} \times \mathrm{T}$ crossbred ewes was 0.23 lamb higher at birth and 0.19 lamb higher at 90 days than those of Timahdite ewes. Boujenane and Kansari [6] had reported differences of 0.38 and 0.27 lamb for litter size at birth and at weaning, respectively between ewes of the same genetic groups lambing in the autumn season. Moreover, the superiority of D'man crossbred ewes compared to Timahdite ewes for litter size at birth and at 90 days is consistent with the results of Boujenane et al. [5], Boujenane and Kansari [7] and El Fadili et al. [10] who found that the difference for litter size between 1/2-D' man and local ewes lambing in the autumn is more than 0.4 lamb.

Lambing season had significant effects on litter size at 90 days but did not affect litter size at birth. Ewes lambing in the spring weaned 0.10 and 0.49 lamb more than those lambing in the autumn and summer, respectively. The high lamb mortality due to heat, low milk yield of dams and poor pasture conditions may explain the low litter size at 90 days of summer-lambing ewes. On the contrary, the lack of lambing season effects on litter size at birth was not consistent with the decline of litter size at birth by 0.62 lamb between April and September for Finn crossbred ewes [14].

Litter weights of $\mathrm{D} \times \mathrm{T}$ crossbred ewes were $0.51 \mathrm{~kg}$ and $4.1 \mathrm{~kg}$ heavier at birth and at 90 days, respectively, than those of Timahdite ewes. These differences may be explained by the high litter size at birth and at weaning of $\mathrm{D} \times \mathrm{T}$ ewes. The litter weight difference between $\mathrm{D} \times \mathrm{T}$ crossbred and Timahdite ewes is in the range of those reported by Aboul-Naga et al. [1] for Finnsheep crosses and subtropical breeds in Egypt.

Ewes lambing in the spring had the heaviest litter weight at birth, followed by those lambing in the autumn, then those lambing in the summer. However, autumn-lambing ewes weaned $3.1 \mathrm{~kg}$ and $17.7 \mathrm{~kg}$ weight more than those of spring- and summer-lambing ewes, respectively. These differences may be explained by feeding management conditions during the gestation of ewes and 
growth of lambs at different seasons. The pregnancy of spring-lambing ewes coincided with a rich pasture that occurred from January to April resulting in a high birth weight of lambs, and hence in a high litter weight at birth. This also coincided with the period of growth of lambs born from autumnlambing ewes resulting in a high litter weight at 90 days.

\subsection{Lamb weights and survival}

Season of birth had significant effects on all lamb traits studied, whereas genetic group of dam had significant effects on birth weight only. Least squares means and standard errors for lamb weights and survival to 90 days are presented in Table III. Lambs from Timahdite ewes were $0.47 \mathrm{~kg}$ heavier at birth than those from $\mathrm{D} \times \mathrm{T}$ ewes. The low birth weight of $\mathrm{D} \times \mathrm{T}$ progeny may be due to their higher litter size, which is the result of genes inherited from their D'man maternal grand-sire. Boujenane et al. [4] found that the birth weights of twin and triplet lambs were $79 \%$ and $63 \%$, respectively, of the birth weight of singles. Moreover, Boujenane et al. [4] reported that the linear regression coefficient of birth weight on percentage of D'man inheritance was $-18 \mathrm{~g}$. Likewise, El Fadili et al. [10] observed a decrease in birth weight in relation to the percentage of D'man breeding. Also, Cochran et al. [8] found that lambs from 1/4-Finnsheep, 3/4-Dorset ewes were $0.64 \mathrm{~kg}$ lighter at birth than lambs from purebred Dorset ewes.

Spring-born lambs were $0.68 \mathrm{~kg}$ and $0.71 \mathrm{~kg}$ heavier at birth than autumn- and summer-born lambs, respectively. The end of pregnancy of spring-lambing dams occurred during the best period of the year with regards to pasture and temperature. This result was in agreement with that of Sormunen-Cristian and Suvela [17] who found a significant effect of birth season (spring: March-May; summer: June-August; autumn: SeptemberNovember; and winter: December-February) on lamb birth weight with a conflicting effect for Finnish Landrace and crossbred lambs. Similarly, Notter et al. [15] reported that lambs born in the winter (January-February) were the heaviest and weighed more than lambs born in either the autumn (November-January) or spring (March-April). They explained the low birth weight of springborn lambs by the greater prolificacy of their dams.

Lambs born in the autumn were $0.24 \mathrm{~kg}$ and $2.70 \mathrm{~kg}$ heavier at 30 days and $3.9 \mathrm{~kg}$ and $11.1 \mathrm{~kg}$ heavier at 90 days than those born in the spring and summer, respectively. Preweaning growth of lambs born in the autumn occurred during the best grazing period, whereas those born in the spring and summer reached the age of 30 days and 90 days in hot weather and in poorer grazing conditions resulting in low weights. These results were not consistent with those of Gould and Whiteman [11] who found that spring-born lambs, growing during normally warm summer months, were heavier at weaning than autumn-born lambs, growing during normally cool late autumn.

Season of birth had significant effects on lamb survival but not dam's genetic group. Survival of lambs born in the autumn and spring was $42 \%$ higher than that of lambs born in the summer. This is mainly a result of a poorer pasture and hot temperature during the summer. Sormunen-Cristian and Suvela [17] found that mortality from birth to 150 days of Finnsheep and crossbred lambs born in the spring, summer, autumn and winter was $17.7 \%, 15.1 \%, 10.8 \%$ and $14.0 \%$, respectively. The high mortality occurring in the spring was due to the largest litter size and to insufficient supervision during lambing.

\section{CONCLUSION}

These results showed that $\mathrm{D} \times \mathrm{T}$ crossbred ewes were more productive than the non-prolific local Timahdite breed at any lambing season of the year. Therefore, breeders that have good management conditions might successfully adopt this breed type. Likewise, flocks that rely on pasture 
for their nutrition should avoid the summer lambing because of low ewe and lamb performance resulting from lack of feed and hot temperature.

\section{ACKNOWLEDGEMENTS}

The authors express their appreciation to $\mathrm{Mr}$. Abdellatif MAROUANE and to the staff of the Had Soualem farm of the 'Société Nationale de Développement de l'Élevage' for their help.

\section{REFERENCES}

[1] Aboul-Naga A.M., Aboul-Ela M.B., Mansour H., Gabr M., Reproductive performance of Finn sheep and crosses with subtropical breeds under accelerated lambing, Small Ruminant Res. 2 (1989) 143-150.

[2] Boujenane I., The D'man, in: Fahmy M.H. (Ed.), Prolific Sheep, CAB International, Oxon, UK, 1996, pp. 109-120.

[3] Boujenane I., Les Ressources Génétiques Ovines au Maroc (Sheep Genetic Resources in Morocco), Actes Editions, Rabat, Morocco, 1999.

[4] Boujenane I., Bradford G.E., Berger Y.M., Chikhi A., Genetic and environmental effects on growth to one year and viability of lambs from a crossbreeding study of D'man and Sardi breeds, J. Anim. Sci. 69 (1991) 39893998.

[5] Boujenane I., Bradford G.E., Famula T.R., Inheritance of litter size and its components in crosses between the D'man and Sardi breeds of sheep, J. Anim. Sci. 69 (1991) 517-524.

[6] Boujenane I., Kansari J., Lamb production and its components from purebred and crossbred mating types, Small Ruminant Res. 43 (2002) 115-120.

[7] Boujenane I., Kansari J., Productivité des brebis Timahdite et croisées D'man $\times$ Timahdite en station et chez les éleveurs au Maroc, Rev. Élev. Méd. Vét. Pays Trop. (2004) in press.

[8] Cochran K.P., Notter D.R., McClaugherty F.S., A comparison of Dorset and Finnish Landrace crossbred ewes, J. Anim. Sci. 59 (1984) 329337.

[9] Duncan D.B., Multiple range and multiple F tests, Biometrics 11 (1955) 1-42.

[10] El Fadili M., Michaux C., Detilleux J., Leroy P.L., Comparison of five crossbreeding types involving Timahdite, D'man and improved terminal sire breeds of sheep: ewe reproduction, lamb survival and growth performance, Anim. Sci. 71 (2000) 435-441.

[11] Gould M.B., Whiteman J.V., Association of certain variables with the performance of spring vs. fall-born lambs, J. Anim. Sci. 33 (1971) 531-536.

[12] Lahlou-Kassi A., Marie M., Sexual and ovarian function of the D'man ewe, in: Land R.B., Robinson D.W. (Eds.), Genetic of Reproduction in Sheep, Butterworths, London, UK, 1985, pp. 245-260.

[13] Lahlou-Kassi A., Berger Y.M., Bradford G.E., Boukhliq R., Tibary A., Derqaoui L., Boujenane I., Performance of D'man and Sardi sheep on accelerated lambing. I. Fertility, litter size, postpartum anoestrus and puberty, Small Ruminant Res. 2 (1989) 225239.

[14] Notter D.R., Copenhaver J.S., Performance of Finnish Landrace crossbred ewes under accelerated lambing. I. Fertility, prolificacy and ewe productivity, J. Anim. Sci. 51 (1980) 1033-1042.

[15] Notter D.R., Kelly R.F., McClaugherty F.S., Effects of ewe breed and management system on efficiency of lamb production: II. Lamb growth, survival, and carcass characteristics, J. Anim. Sci. 69 (1991) 22-33.

[16] SAS/STAT, User's Guide, Release 6.03 Edition, SAS Institute, Cary, NC, 1988.

[17] Sormunen-Cristian R., Suvela M., Out-ofseason lambing of Finnish Landrace ewes, Small Ruminant Res. 31 (1999) 265-272. 